\title{
IMPROVING GRADE OF INDIAN CHROMITE ORES BY HIGH-GRADIENT MAGNETIC SEPARATION
}

\author{
R. BHIMA RAO, B. DAS AND S.R.S. SASTRI \\ Regional Research Laboratory, Council for Scientific and \\ Industrial Research, Bhubaneswar 751 013, India \\ (Received July 3, 1996, in final form August 12, 1996)
}

\begin{abstract}
Investigations were carried out to improve the chromium-to-iron ratio of two off-grade chromite samples from Orissa, India, having different physical natures. The results of these investigations indicated that the chromium-to-iron ratio could be improved from 1.85 to 3.0 with around $10 \%$ to $30 \%$ recoveries by high-intensity magnetic separation of the washed ores. A common flowsheet is suggested for processing of these two ores.
\end{abstract}

\section{INTRODUCTION}

The major portion of the Indian chromite ore reserves are located in Sukinda-Naushai belt of Orissa, and belong to the lateritic iron group ores group. Approximately $40 \%$ of these reserves are suitable for metallurgical use, $33 \%$ for refractory making and $27 \%$ for chemical industries [1]. The purpose for which a given ore can be used depends on the chromium-to-iron ratio besides the $\mathrm{Cr}_{2} \mathrm{O}_{3}$ content. Ores having chromium-to-iron ratio above 2.8 are considered suitable for metallurgical purposes and those with the ratio between 2.8 and 1.8 for charge chrome/refractory uses, while the rest with ratio below 1.8 are used for production of chemical [1].

Statistical review [1] reveals that metallurgical industry accounts for about $77 \%$ of the total annual consumption of chromite ore in India. The refractory industries 
consume around $15 \%$ and the rest is used for producing chemicals. Now there is a heavy demand for chromite ore due to increase in the installed capacity of plants. In addition to this, many new ferroalloy plants are coming up in the country. Due to a sudden increase in the demand for the consumption of high-grade ore containing chromium-to-iron ratio above 3.0 by metallurgical industries, and the limited reserves of such high-grade ore resources, it has become necessary to improve the quality of medium-grade ores.

Investigations were, therefore, carried out on two ore samples selected from different mining localities of Orissa (India). These are similar in chemical characteristics but distinctly different in their mineralogical and physical characteristics. The results of these investigations are discussed in this paper.

\section{MATERIALS AND METHODS}

Ferruginous chromite ore samples of Orissa region having chromium-to-iron ratio 1.9 and 1.8 were supplied by M/s Misrilal Mines Pvt. Ltd., Chaibasa [2] and m/s The Orissa Mining Corporation Ltd., Bhubaneswar [3], respectively. These samples were designated as A and B.

Representative samples of A and B were stage crushed to pass through crushing rolls set to $1.5 \mathrm{~mm}$ gap. Each crushed product was subsequently ground at different time intervals in a batch ball mill of $300 \times 300 \mathrm{~mm}$ size, with mill feed at $40 \%$ filling. The sample as received and each mill product were size analysed by wet screening. All size fractions were analysed for chromium content. The fractions below $50 \mu \mathrm{m}$ were considered as slimes.

Based on these results, large-scale continuous scrubbing and washing studies were carried out on both A and B samples using spiral classifier $225 \mathrm{~mm}$ dia $\times 1800 \mathrm{~mm}$ long (M/s Mineral Processing Equipment, Bombay), at a rate of $80 \mathrm{~kg} / \mathrm{h}$ of ore, and $250 \ell / \mathrm{h}$ of water.

The washed products of samples A and B from the classifier were subjected to magnetic separation at currents of $1.0 \mathrm{~A}$ and $1.5 \mathrm{~A}$ by using dry belt magnetic 
separator (Boxmag Rapid, single-disc type, model Log 1.4), at a rate of $70 \mathrm{~kg} / \mathrm{h}$. The other variables of the magnetic separator were maintained constant at the following levels:

-disc speed: $30 \mathrm{rpm}$

-belt speed: $0.1 \mathrm{~m} / \mathrm{s}$

-gap: $2 \mathrm{~mm}$.

Mineralogical studies were carried out by $\mathbf{x}$-ray diffraction and elemental analysis for chromium and iron were carried out by wet methods.

\section{RESULTS AND DISCUSSION}

The physical, chemical and mineralogical characteristics of the two samples are shown in Table 1. Results of laboratory and large-scale continuous washing tests are shown in Tables 2 and 3, respectively. Results of magnetic separation on washed products after crushing at $1.5 \mathrm{~mm}$ set roll crushers are shown in Table. 4. Summary of the results from continuous washing followed by magnetic separation are shown in Table 5.

It is observed from the data presented in Table 1 that both the samples A and B do not differ significantly in $\mathrm{Cr}_{2} \mathrm{O}_{3}$ content, but are physically distinct in nature. Sample A is hard, lumpy and rich in $\mathrm{Cr}_{2} \mathrm{O}_{3}$ content, and sample $\mathrm{B}$ is friable, fine and soft ore. Further, it can also be seen that sample $A$ is associated with $\mathrm{FeO}(\mathrm{Cr}, \mathrm{Al})_{2} \mathrm{O}_{3}-$ Ferran type chromite and sample $\mathrm{B}$ is with $\mathrm{Fe}(\mathrm{Al}, \mathrm{Cr})_{2} \mathrm{O}_{3}$ chromite type mineral.

From the data in Tables 2 and 3 , it can be seen that the chromium content can be significantly improved by simple washing. It is also concluded from the data in Table 2 that further grinding of the samples will cause a loss of $\mathrm{Cr}_{2} \mathrm{O}_{3}$ in the fines. These observations are confirmed by the results of large scale continuous scrubbing tests made on these samples shown in Table 3. The chromium content improved from $47 \%$ to around $52 \%$. However, the chromium-to-iron ratio, 2.2 , obtained in both products of samples $\mathrm{A}$ and $\mathrm{B}$ is still not suitable for some metallurgical industries. 
R. BHIMA RAO ET AL.

Table $1 \quad$ Characteristics of chromite ores

\begin{tabular}{|c|c|c|}
\hline Details & Sample A & Sample B \\
\hline Mine lease & $\begin{array}{l}\text { M/s Misrilal Mines Pvt. Ltd. } \\
\text { Chaibasa }\end{array}$ & $\begin{array}{l}\text { M/s Orissa Mining Corp. } \\
\text { Bhubaneswar }\end{array}$ \\
\hline Location & Sukinda Valley, Orissa & Sukinda Valley, Orissa \\
\hline Nature & Lumpy, hard, ferruginous & Fines, soft, friable, ferruginous \\
\hline $\begin{array}{l}\mathrm{d} 80, \text { passing size of } \\
\text { ROM ore }[\mathrm{mm}]\end{array}$ & 6.5 & 2.5 \\
\hline Mineral constituents & $\begin{array}{l}\text { Chromite }\left[\mathrm{FeO},(\mathrm{Cr}, \mathrm{Al})_{2} \mathrm{O}_{3} \text { ferran }\right. \\
\text { type] } \\
\text { Goethite, hematite, magnetite, } \\
\text { hydroxides of chromium, iron } \\
\text { aluminium silicates, quartz }\end{array}$ & $\begin{array}{l}\text { Chromite }(\mathrm{Fe}, \mathrm{Al}, \mathrm{Cr})_{2} \mathrm{O}_{3} \text { and } \\
\mathrm{MgCr}_{2} \mathrm{O}_{3} \\
\text { Picrochromite, goethite, } \\
\text { hematite, magnetite, hydroxides } \\
\text { of chromium, iron, aluminium } \\
\text { silicates, quartz }\end{array}$ \\
\hline $\mathrm{Cr}_{2} \mathrm{O}_{3}$ content & $48.3 \%$ & $47.3 \%$ \\
\hline $\mathrm{Cr} / \mathrm{Fe}$ & 1.91 & 1.85 \\
\hline
\end{tabular}

Table 2 Grade and recovery of $\mathrm{Cr}_{2} \mathrm{O}_{3}$ in batch washing

\begin{tabular}{||c|c|c|c|c||}
\hline \multirow{2}{*}{} & \multicolumn{2}{|c|}{ Sample A } & \multicolumn{2}{c||}{ Sample B } \\
\cline { 2 - 5 } & Grade [\%] & Recovery [\%] & Grade [\%] & Recovery [\%] \\
\hline Original feed & 48.3 & 100 & 47.3 & 100 \\
\hline Washed material & 55.8 & 93 & 53.9 & 95 \\
\cline { 1 - 5 } $\begin{array}{l}\text { Ground and } \\
\text { washed material }\end{array}$ & \multicolumn{5}{|c}{} \\
\cline { 1 - 5 } Time of grinding & 57.1 & 86 & 54.9 & 88 \\
\hline 0 min & 58.1 & 78 & 55.2 & 84 \\
\hline 3 min & 58 & 73 & 55.9 & 74 \\
\hline 5 min & & & & \\
\hline
\end{tabular}


Table 3 Results of continuous washing tests

\begin{tabular}{||c|c|c|c|c|c||}
\hline \hline Sample & Details & Weight \% & $\mathrm{Cr}_{2} \mathrm{O}_{3} \%$ & $\mathrm{FeO} \%$ & $\mathrm{Cr} / \mathrm{Fe}$ \\
\hline A & Feed & 100 & 48.3 & 22 & 1.91 \\
\hline & Product & 87 & 52.2 & 20.5 & 2.22 \\
\hline & Slimes & 13 & 22.4 & 31.6 & 0.62 \\
\hline B & Feed & 100 & 47.3 & 22.3 & 1.85 \\
\hline & Product & 85.5 & 51.5 & 20.8 & 2.16 \\
\hline & Slimes & 14.5 & 22.9 & 30.9 & 0.65 \\
\hline
\end{tabular}

Feed rates: chromite: $80 \mathrm{~kg} / \mathrm{h}$, water: $250 \mathrm{l} / \mathrm{h}$

Table 4 Results of magnetic separation tests on washed products

\begin{tabular}{||l|l|c|c|c|c||}
\hline Sample & Details & Weight \% & $\mathrm{Cr}_{2} \mathrm{O}_{3} \%$ & $\mathrm{FeO} \%$ & $\mathrm{Cr} / \mathrm{Fe}$ \\
\hline $\mathrm{A}$ & Feed & 87 & 52.2 & 20.5 & 2.22 \\
\hline & Mags 1(*) & 46.4 & 51.5 & 24.1 & 1.86 \\
\hline & Mags 2 (\#) & 29.1 & 55.4 & 15.3 & 3.15 \\
\hline & Non-mags & 11.5 & 48.2 & 17.2 & 2.45 \\
\hline & Feed & 85.5 & 51.5 & 20.8 & 2.16 \\
\hline & Mags 1 (*) & 47.9 & 50 & 22.6 & 1.93 \\
\hline & Mags 2 (\#) & 28.5 & 53.6 & 19 & 2.46 \\
\hline & Non-mags & 9.1 & 53.4 & 15.6 & 2.99 \\
\hline
\end{tabular}

Feed rate: $70 \mathrm{~kg} / \mathrm{h}$

* Magnetic product at $1.0 \mathrm{~A}$

\# Weakly magnetic product between 1 and $1.5 \mathrm{~A}$ 
Table 5 Summary of results

\begin{tabular}{||l|c|c|c|c|c|c||}
\hline \multirow{2}{*}{ Detail } & \multicolumn{3}{|c|}{ Sample A } & \multicolumn{3}{c||}{ Sample B } \\
\cline { 2 - 7 } & Feed & $\begin{array}{c}\text { Product } \\
{[\mathrm{P} 2]}\end{array}$ & $\begin{array}{c}\text { Product } \\
{[\mathrm{P} 1+\mathrm{P} 3]}\end{array}$ & Feed & $\begin{array}{c}\text { Product } \\
{[\mathrm{P} 3]}\end{array}$ & $\begin{array}{c}\text { Product } \\
{[\mathrm{P} 1+\mathrm{P} 2]}\end{array}$ \\
\hline $\mathrm{Cr}_{2} \mathrm{O}_{3}$ & 48.3 & 55.4 & 50.8 & 47.3 & 53.4 & 51.3 \\
\hline $\mathrm{FeO}$ & 22.1 & 15.3 & 22.7 & 22.3 & 15.6 & 21.3 \\
\hline $\mathrm{Cr} / \mathrm{Fe}$ & 1.91 & 3.15 & 1.95 & 1.85 & 2.99 & 2.1 \\
\hline Yield [\%] & 100 & 29 & 58 & 100 & 9 & 7.6 \\
\hline Recovery [\%] & 10 & 33 & 61 & 100 & 10 & 83 \\
\hline
\end{tabular}

The results of high-intensity magnetic separation tests on the washed ore samples given in Table 4 indicate that a product having chromium-to-iron ratio of around 3.0 can be obtained from both these samples. However, in the case of sample A, the weakly magnetic product is the desired one, while in the case of sample $B$ the non-magnetic fraction is the desired one.

The probable reason for such a difference in the response to magnetic separation of these two ores is that samples A and B are associated with two different structural chromite minerals such as $\mathrm{Fe}(\mathrm{Al}, \mathrm{Cr})_{2} \mathrm{O}_{3}$ and $\mathrm{FeO}(\mathrm{Cr}, \mathrm{Al})_{2} \mathrm{O}_{3}$, respectively (Table 1). Such variations in structure influence the magnetic properties and separation characteristics. These views are supported by other studies [4 to 8 ]. Thus, from the data presented in Table 5 it is seen that chromite concentrates having chromium-to-iron ratio 3.0 can be obtained with $33 \%$ and $10 \%$ recoveries from samples $A$ and $B$, respectively. The other material is suitable for making charge chrome. A common flowsheet shown in Figure 1 is suggested for both these ores.

\section{CONCLUSIONS}

Desliming of the two chromite samples studied gave almost the same grade of product in spite of differences in physical and mineralogical properties. 
High-intensity magnetic separation of these washed chromite samples yielded fractions having chromium-to-iron ratio around 3.0. A common flowsheet involving high-intensity magnetic separation of crushed and washed chromite material is proposed to upgrade both types of the ores to products having chromium-to-iron ratio around 3.0.

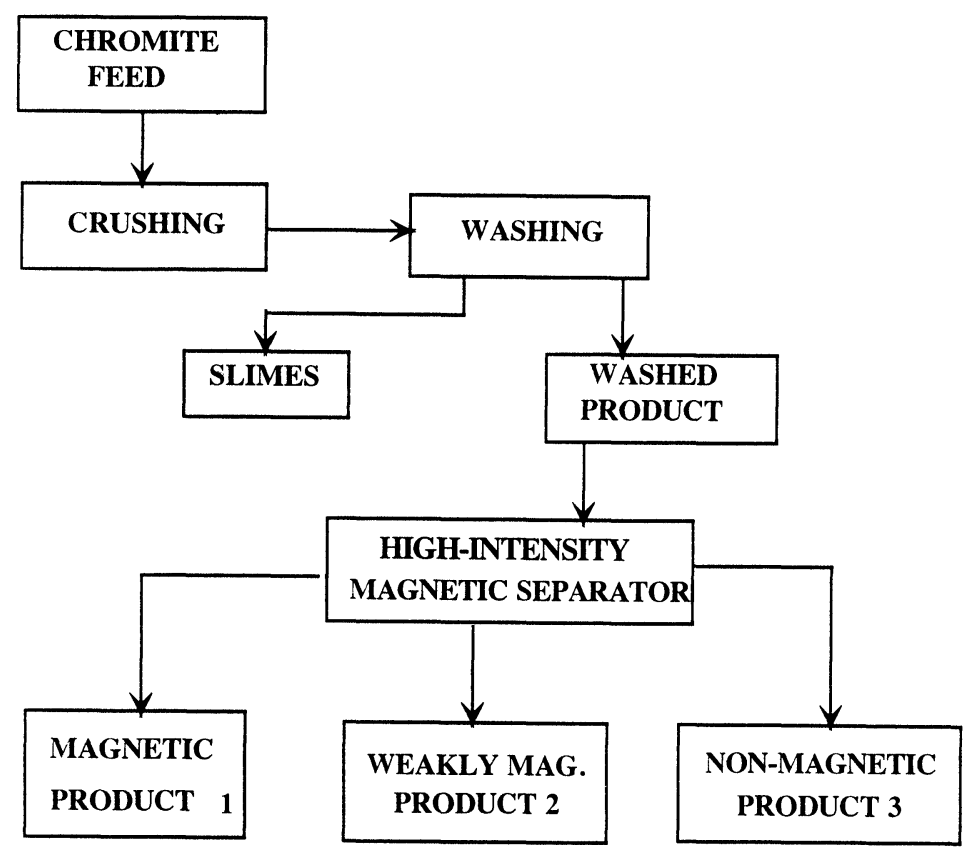

Fig. 1 Schematic flowsheet for upgrading $\mathrm{Cr} / \mathrm{Fe}$ ratio of ferruginous chromite ores.

Products of $\mathrm{Cr} / \mathrm{Fe}=3.0$ for samples $\mathrm{A}\left({ }^{*}\right)$ and $\mathrm{B}(\#)$.

\section{ACKNOWLEDGMENTS}

The authors are grateful to Professor H.S. Ray, Director of the Laboratory, for permitting to publish this paper. 


\section{REFERENCES}

[1] Mineral Yearbook 1990, Indian Bureau of Mines, Nagpur (1992)

[2] R. Bhima Rao et al.: Beneficiation of chromite from Saruabil mines. Report for M/s Misrilal Mines Pvt. Ltd., Chaibasa. Prepared by Regional Research Laboratory (CSIR), Bhubaneswar (1983)

[3] R. Bhima Rao et al.: Beneficiation of chromite from Sukarangi mines. Report for M/s Orissa Mining Corporation Ltd., Bhubaneswar. Prepared by Regional Research Laboratory (CSIR), Bhubaneswar (1981)

[4] H.C. Howkes: U.S. Geol. Survey Bull. A973 (1951)

[5] I.V.R. Murty and G. Gopalakrishna: Remanence hysteresis properties of chromites. Proc. Ind. Acad. Sci. 91 (1982), 159

[6] A.T. Rao: Magnetic chromites from Kondapalli, Andhrapradesh. Ind. Miner. Mag. 42 (1978), 406

[7] A. Kumar and M.S. Bhalla: Source of stable remanence in chromite ores. Geophys. Res. Lett.11 (1984), 177

[8] J. Svoboda: Magnetic Methods for the Treatment of Minerals. Elsevier, Amsterdam, 1987

R. Bhima Rao: for biography, see Magn. Electr. Sep. 8 (1997), 115

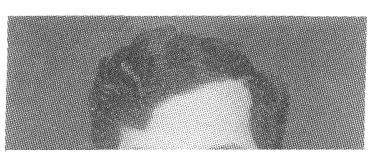

Bisweswar Das obtained his post-graduate degrees in chemistry and minerals engineering. He has also obtained his doctorate degree in chemistry from Sambalpur University, India. Presently he is working 
S.R.S. Sastri is the Deputy Director of the Regional

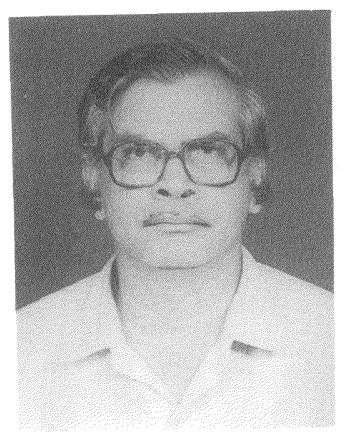
Research Laboratory, Bhubaneswar, India, with more than 30 years of experience in process development and mineral processing. He received his B. Tech. (Chem. Eng.) degree from the Andhra University, Waltair, India, and has more than 50 publications to his credit.

Keywords: chromite, hematite, magnetite, ferron, magnetic separation 